\title{
The Potential Impact of Biofield Treatment on Physical, Structural and Mechanical Properties of Stainless Steel Powder
}

\author{
Mahendra Kumar Trivedi', Gopal Nayak', Shrikant Patil', Rama Mohan Tallapragada1, Omprakash Latiyal ${ }^{2}$ and Snehasis Jana ${ }^{2 *}$ \\ ${ }^{1}$ Trivedi Global Inc., 10624 S Eastern Avenue Suite A-969, Henderson, NV 89052, USA \\ ${ }^{2}$ Trivedi Science Research Laboratory Pvt. Ltd., Hall-A, Chinar Mega Mall, Chinar Fortune City, Hoshangabad Rd., Bhopal-462026, Madhya Pradesh, India
}

\begin{abstract}
Stainless steel (SS) has gained extensive attention due to its high corrosion resistance, low maintenance, familiar lustre, and superior mechanical properties. In SS, the mechanical properties are closely related with crystal structure, crystallite size, and lattice strain. The aim of present study was to evaluate the effect of biofield treatment on structural, physical and mechanical properties of SS powder. SS (Grade-SUS316L) powder was divided into two parts denoted as control and treatment. The treatment part was received Mr. Trivedi's biofield treatment. Control and treated SS samples were characterized using particle size analyzer, X-ray diffraction (XRD), and Fourier transform infrared (FT-IR) spectroscopy. Result showed that biofield treatment has significantly reduced the particle size $d_{10}$, $d_{50}, d_{90}$, and $d_{99}$ (size, below which 10,50,90, and $99 \%$ particles were present, respectively) of SS powder up to $7.42,12.93,30.23$, and $41.38 \%$ respectively, as compared to control. XRD result showed that the unit cell volume of SS was altered after biofield treatment. Moreover, crystallite size was significantly reduced upto $70 \%$ in treated SS as compared to control. The yield strength calculated using Hall-Petch equation, was significantly increased upto $216.5 \%$ in treated SS, as compared to control. This could be due to significant reduction of crystallite size in treated SS after biofield treatment. In FT-IR spectra, intensity of the absorption peak at wavenumber $1107 \mathrm{~cm}^{-1}$ (control) attributing to $\mathrm{Fe}-\mathrm{O}-\mathrm{H}$ bond was diminished in case of treated SS. These findings suggest that biofield treatment has substantially altered the structural, physical and mechanical properties of treated SS powder.
\end{abstract}

Keywords: Biofield treatment; Austenitic stainless steel; X-ray diffraction; FT-IR; SUS316L

\section{Introduction}

Stainless steel (SS), invented in the beginning of the $20^{\text {th }}$ century, is known for high resistance to corrosion and staining. It primarily consists of iron $(\mathrm{Fe})$, nickel $(\mathrm{Ni})$, chromium $(\mathrm{Cr})$ and molybdenum (Mo). Based on microstructure, SS is classified into three categories: austenitic, ferritic, and martensitic. The austenitic SS is mainly responsible for corrosion resistance properties and nonmagnetic behaviour. It exist in the form of face centred cubic (FCC) crystal structure with nickel (12-15 wt.\%), chromium (16-18 wt.\%). Due to high content of $\mathrm{Cr}$, it is suitable for high corrosion resistance applications [1]. Beside this, the superior mechanical properties of austenitic SS is very useful for nuclear fuel clad tubes and fuel assembly [2]. Nano crystalline austenitic SS is mainly consist of large volume fraction of crystallite and crystallite boundaries, which significantly alters their physical and mechanical properties [3]. Further, it is well known fact that the crystallite size of metals are inversely proportional to its yield strength and hardness [4]. Additionally, the mechanical properties of austenitic SS strongly depends on the chemical composition and lattice strain i.e. higher the lattice strain, higher is yield strength. Thus, it is possible to change the mechanical properties of metals by modulating the crystallite size and lattice strain. Currently, in steel industries, mechanical properties of austenitic SS are mainly controlled through various heat treatment process such as annealing, normalizing and quenching etc [5-7]. In heat treatment process, crystallite refinement is strongly required by steel industries in order to increase the strength of material [8]. Furthermore, the heat treatment processes require costly equipment set up and high power supply, to modulate the mechanical properties. Due to this, it becomes important to study an alternative and economically safe approach that could be utilized to modify the physical and structural properties of SS powder.

Recently, several researchers have reported that human body functions as macroscopic quantum system [9-13]. The famous Physicist Feyman had explained the scientific aspects behind quantum biology using quantum-electrodynamics and quantum-chromo dynamics [14]. In other words, each quantum system consists of quantum-domains that have some oscillators within, which generate the potential field. Due to this, a human has ability to harness the energy from environment/universe and can transmit into any object (living or nonliving) around the Globe. The object(s) always receive the energy and responded into useful way that is called biofield energy. This process is known as biofield treatment.

Mr. Trivedi's biofield treatment has known to alter the characteristics in various things at atomic, molecular and physical level in many fields such as material science [15-22], microbiology [23-25], biotechnology $[26,27]$ and agriculture [28-30]. The biofield treatment has also shown significant results in graphite carbon, for instance, the unit cell volume was decrease by $1 \%$ and crystallite size was increased by $100 \%$ after treatment [16]. In the present study, we evaluated for the first time, an impact of biofield treatment on physical, structural and mechanical properties SS powder.

*Corresponding author: Snehasis Jana, Trivedi Science Research Laboratory Pvt. Ltd., Hall-A, Chinar Mega Mall, Chinar Fortune City, Hoshangabad Rd. Bhopal-462026, Madhya Pradesh, India, Tel: +91-755-6660006; E-mail: publication@trivedisrl.com

Received July 07, 2015; Accepted July 20, 2015; Published July 25, 2015

Citation: Trivedi MK, Nayak G, Patil S, Tallapragada RM, Latiyal O, et al. (2015) The Potential Impact of Biofield Treatment on Physical, Structural and Mechanical Properties of Stainless Steel Powder. J Appl Mech Eng 4: 173. doi:10.4172/21689873.1000173

Copyright: (c) 2015 Trivedi MK, et al. This is an open-access article distributed under the terms of the Creative Commons Attribution License, which permits unrestricted use, distribution, and reproduction in any medium, provided the original author and source are credited. 
Citation: Trivedi MK, Nayak G, Patil S, Tallapragada RM, Latiyal O, et al. (2015) The Potential Impact of Biofield Treatment on Physical, Structural and Mechanical Properties of Stainless Steel Powder. J Appl Mech Eng 4: 173. doi:10.4172/2168-9873.1000173

\section{Experimental}

The SS powder (Grade-SUS316L) was purchased from Alfa Aesar, USA. The sample was equally divided into two parts, considered as control and treated. Treated group was in sealed pack and handed over to Mr. Trivedi for biofield treatment under laboratory condition. Mr. Trivedi provided the treatment through his energy transmission process to the treated group without touching the sample. The control and treated samples were characterized using X-ray Diffraction (XRD), surface area analyzer, and Fourier transform infrared (FT-IR) spectroscopy.

\section{Particle size analysis}

For particle size analysis, laser particle size analyzer SYMPATEC HELOS-BF was used, which had a detection range of 0 1-875 $\mu \mathrm{m}$. The particle size data was collected in the form of a chart of particle size $v s$. cumulative percentage. Four parameters of particle sizes viz. $\mathrm{d}_{10} \mathrm{~d}_{50}, \mathrm{~d}_{90}$, and $\mathrm{d}_{99}$ (size below which $10 \%, 50 \%, 90 \%$, and $99 \%$ particles are present, respectively) were calculated from the particle size distribution curve. The percent change in particle size were calculated using following equation:

$$
\% \text { change in particle size, } \mathrm{d}_{10}=\frac{\left[\left(\mathrm{d}_{10}\right)_{\text {Treated }}-\left(\mathrm{d}_{10}\right)_{\text {Control }}\right]}{\left(\mathrm{d}_{10}\right)_{\text {Control }}} \times 100
$$

Where, $\left(\mathrm{d}_{10}\right)_{\text {Control }}$ and $\left(\mathrm{d}_{10}\right)_{\text {Treated }}$ are the particle size, $\mathrm{d}_{10}$ of control and treated samples respectively. Similarly, the percent change in particle size $d_{50} d_{90}$ and $d_{99}$ were calculated. For particle size analysis treated part was divided into four parts, referred as T1, T2, T3, and T4.

\section{X-ray diffraction study}

XRD analysis was carried out on Phillips, Holland PW 1710 X-ray diffractometer system, which had a copper anode with nickel filter. The radiation of wavelength used by the XRD system was $1.54056 \AA$. The data obtained from this XRD were in the form of a chart of $2 \theta$ vs. intensity and a detailed table containing peak intensity counts, $d$ value $(\AA)$, peak width $\left(\theta^{\circ}\right)$, relative intensity (\%) etc. Additionally, PowderX software was used to calculate lattice parameter and unit cell volume.

The crystallite size $(G)$ was calculated by using formula:

\section{$\mathrm{G}=\mathrm{k} \lambda /(\mathrm{b} \operatorname{Cos} \theta)$,}

Here, $\lambda$ is the wavelength of radiation used and $\mathrm{k}$ is the equipment constant $(=0.94)$. However, the percentage change in all parameters such as lattice parameter, unit cell volume and crystallite size was calculated using the following equation:

Percent change in lattice parameter $=\left[\left(a_{t}-a_{c}\right) / a_{c}\right] \times 100$

Where, $a_{c}$ and $a_{t}$ are lattice parameter value of control and treated powder samples respectively

Percent change in unit cell volume $=\left[\left(\mathrm{V}_{\mathrm{t}}-\mathrm{V}_{\mathrm{c}}\right) / \mathrm{V}_{\mathrm{c}}\right] \times 100$

Where, $V_{c}$ and $V_{t}$ are the unit cell volume of control and treated powder samples respectively

Percent change in crystallite size $=\left[\left(G_{t}-G_{c}\right) / G_{c}\right] \times 100$

Where, $G_{c}$ and $G_{t}$ are crystallite size of control and treated powder samples respectively. XRD analysis was carried out for control, T1, T3, and T4.

\section{FT-IR Spectroscopy}

To study the impact of biofield treatment at atomic bonding level in SS the FT-IR analysis was carried out using Shimadzu, Fourier transform infrared (FT-IR) spectrometer with frequency range of 300$4000 \mathrm{~cm}^{-1}$. FT-IR analysis was carried out for control and T1.

\section{Results and Discussion}

\section{Particle size analysis}

Particle size analysis result of SS powder are presented in Table 1, Figures 1 and 2. In order to study the effect of biofield treatment on various sizes of particles, four kind of particle size $\left(\mathrm{d}_{10}, \mathrm{~d}_{50}, \mathrm{~d}_{90}\right.$, and $\left.\mathrm{d}_{99}\right)$ were analyzed. Data result showed that smaller particle size $d_{10}$, was reduced from $18.58 \mu \mathrm{m}$ (control) to $17.74,17.36,17.20$, and $17.55 \mu \mathrm{m}$ in $\mathrm{T} 1, \mathrm{~T} 2, \mathrm{~T} 3$, and $\mathrm{T} 4$ respectively (Table 1 ). It indicates that $\mathrm{d}_{10}$ was reduced up to $7.42 \%$ (T3) as compared to control (Figure 1). Medium particle size, $\mathrm{d}_{50}$ was reduced from $44.15 \mu \mathrm{m}$ (control) to $39.64,38.53$, 38.44 , and $38.65 \mu \mathrm{m}$ in treated $\mathrm{T} 1, \mathrm{~T} 2, \mathrm{~T} 3$ and $\mathrm{T} 4$ respectively. It suggests that average particle size, $d_{50}$ was reduced up to $12.93 \%$ (T3) as compared to control. Further, large particle size, $\mathrm{d}_{90}$ was decreased from $93.61 \mu \mathrm{m}$ (control) to $68.80,65.99,65.95$, and $65.31 \mu \mathrm{m}$ in T1, T2, T3, and T4 respectively. Data showed that $\mathrm{d}_{90}$ was significantly reduced upto $30.23 \%$ (T4), as compared to control. In addition, larger particle size $\mathrm{d}_{99}$ was reduced from $152 \mu \mathrm{m}$ (control) to $99.15,95.47,94.93$, and $89.11 \mu \mathrm{m}$ in $\mathrm{T} 1, \mathrm{~T} 2, \mathrm{~T} 3$, and $\mathrm{T} 4$ respectively. It suggests that $\mathrm{d}_{99}$ was substantially reduced upto $41.38 \%$ (T4), as compared to control (Figure 2). Overall, the particle size result indicates that particles of each size i.e. $d_{10}, d_{50}, d_{90}$, and $d_{99}$ were reduced in all treated samples $T 1, T 2, T 3$, and T4. It could be due to breaking down of all kind of powder particles into smaller particles. It is assumed that an energy might be transferred to SS powder through biofield treatment. This energy might induce milling in SS powder and that resulted into breaking down of large particles to smaller [16-18]. Furthermore, average percent changes in particle size are illustrated in Figure 3. It was found that average of percent change in particle sizes $d_{10}, d_{50}, d_{90}$, and $d_{99}$ were reduced by $6.01,12.08,28.9,37.7 \%$, respectively, as compared to control in treated

\begin{tabular}{|c|c|c|c|c|}
\hline Group & $\mathbf{d}_{\mathbf{1 0}}(\boldsymbol{\mu m})$ & $\mathbf{d}_{\mathbf{5 0}}(\boldsymbol{\mu m})$ & $\mathbf{d}_{\mathbf{9 0}}(\boldsymbol{\mu m})$ & $\mathbf{d}_{\mathbf{9 9}}(\boldsymbol{\mu m})$ \\
\hline Control & 18.58 & 44.15 & 93.61 & 152 \\
\hline T1 & 17.74 & 39.64 & 68.8 & 99.15 \\
\hline T2 & 17.36 & 38.53 & 65.99 & 95.47 \\
\hline T3 & 17.20 & 38.44 & 65.95 & 94.93 \\
\hline T4 & 17.55 & 38.65 & 65.31 & 89.11 \\
\hline
\end{tabular}

$\mathrm{T} 1, \mathrm{~T} 2, \mathrm{~T} 3$, and T4 are biofield treated stainless steel samples.

$d_{10}, d_{50}, d_{90}$, and $d 99$ are the sizes below which $10 \%, 50 \%, 90 \%$, and $99 \%$ particles are present, respectively.

Table 1: Particle size of stainless steel (SS) powder

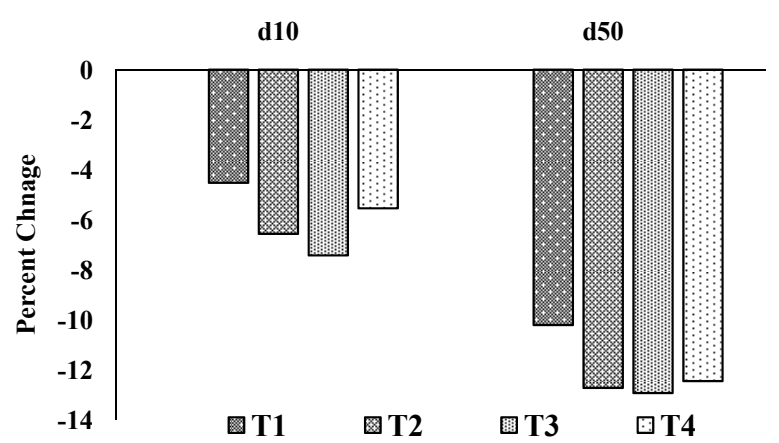

Figure 1: Effect of biofield treatment on percent change in particle size $\mathrm{d}_{10}$ and $\mathrm{d}_{50}$ of stainless steel powder. 


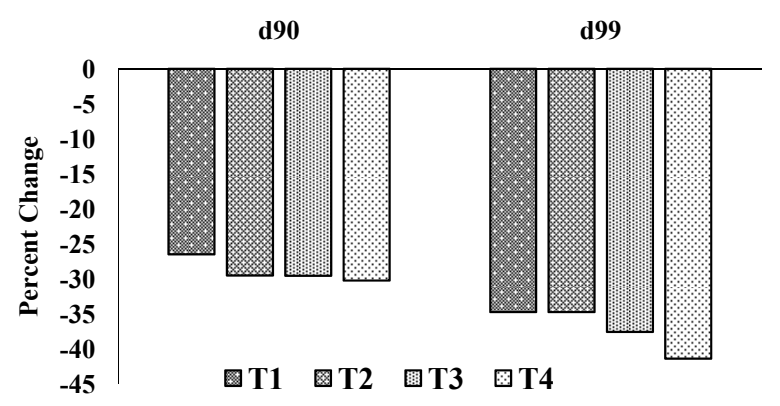

Figure 2: Effect of biofield treatment on percent change in particle size $d_{90}$ and $d_{99}$ of stainless steel powder.

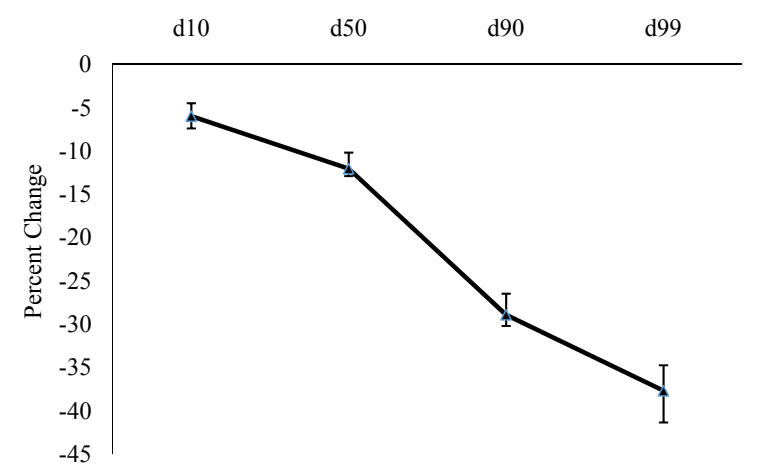

Figure 3: Effect of biofield treatment on percent change of particle sizes of stainless steel powder with respect of control.

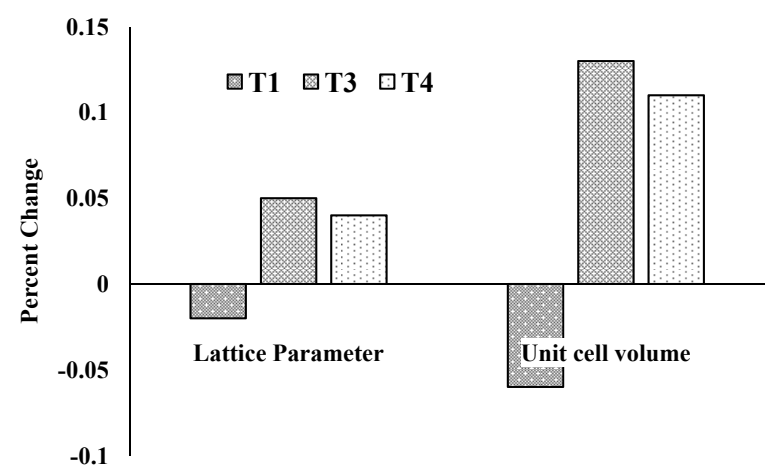

Figure 4: Effect of biofield treatment on lattice parameter and unit cell volume of stainless steel powder.

SS powder. Similar results of particle size reduction in titanium and antimony had been reported by our group in previous studies [15,17].

\section{X-ray diffraction (XRD)}

XRD results of control and treated SS samples are depicted in Figures 4-6. It was found that the lattice parameter of unit cell slightly altered in biofield treated samples (T1:-0.02\%, T2: 0.05\%, T3: 0.04\%) as compared to control. This change in lattice parameter led to alter the unit cell volume slightly by $-0.06 \%, 0.13 \%$, and $0.12 \%$ in treated $\mathrm{T} 1, \mathrm{~T} 3$, and T4 respectively as compared to control (Figure 4). It indicates that both kind of stress (compressive and tensile) might present in treated SS powder, after biofield treatment $[15,16]$. Thus, it is hypothesised that the high-energy milling induced through biofield treatment may lead to generate tensile and compressive stress in SS powder that resulted into alteration of lattice parameter and unit cell volume. Besides this, the crystallite size was computed using Scherrer formula is presented in Figure 5. It was found that crystallite size was $148.44 \mathrm{~nm}$ in control, whereas crystallite size of treated samples was $74.2,44.53$, and 63.61 $\mathrm{nm}$ in $\mathrm{T} 1, \mathrm{~T} 3$ and $\mathrm{T} 4$, respectively. It indicates that crystallite size was significantly reduced by 50,70 , and $57.15 \%$ in treated $\mathrm{T} 1, \mathrm{~T} 3$ and $\mathrm{T} 4$ respectively, as compared to control (Figure 6). The existence of severe lattice strains are evidenced by the change in lattice parameters (Figure 4). Thus, it is assumed that presence of these internal strain may leads to fracture the grains into sub grains and decrease the crystallite size [21]. On the other hand, the relation between strength of material and crystallite size is given by Hall-Patch equation as given below:

$$
\sigma=\sigma_{o}+k / \sqrt{G}
$$

Where, $\sigma$ is strength of the material, $\sigma$ is a material constant for the starting stress for dislocation movement, $\mathrm{k}$ is the strengthening coefficient, $G$ is crystallite size.

Singh et al. reported the $\mathrm{k}=575 \mathrm{MPa} \mu \mathrm{m}^{1 / 2}, \sigma_{\mathrm{o}}=150 \mathrm{MPa}$ for true strain less than 0.02 [31]. Yield strength was computed using these constants and results are shown in Figures 7 and 8. It was found that yield strength of $2086.8 \mathrm{Mpa}$ in control, which increased to 4024.6, 6606.3, and 4669.7 MPa in treated SS samples T1, T3 and T4, respectively. This indicates that the yield strength was significantly enhanced by $92.86,216.5$, and $123.7 \%$ in treated SS samples T1, T3, and $\mathrm{T} 4$ respectively as compared to control. It is already reported that the strength of materials can be modulated by changing the crystallite size. The decrease in crystallite size in treated SS powder results into increase

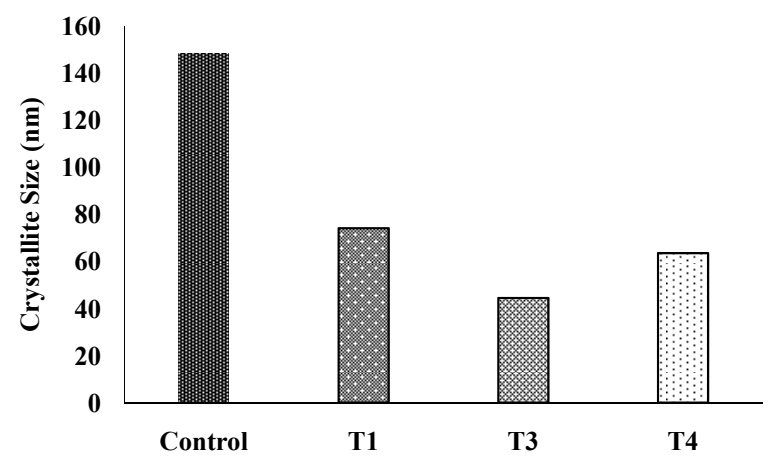

Figure 5: Effect of biofield treatment on crystallite size of stainless steel.

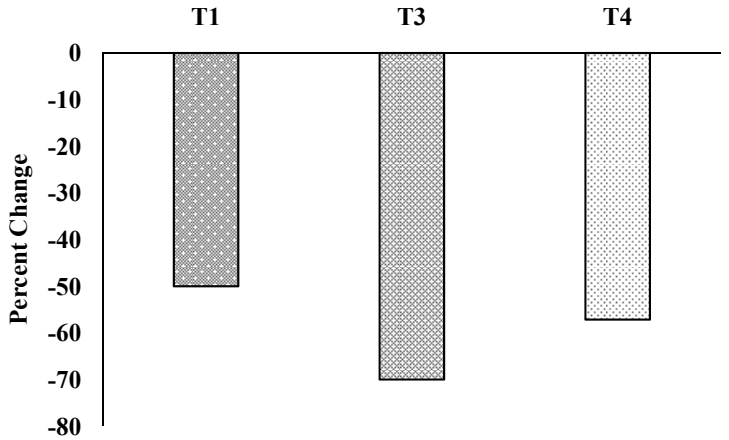

Figure 6: Effect of biofield treatment on percent change in crystallite size of stainless steel. 


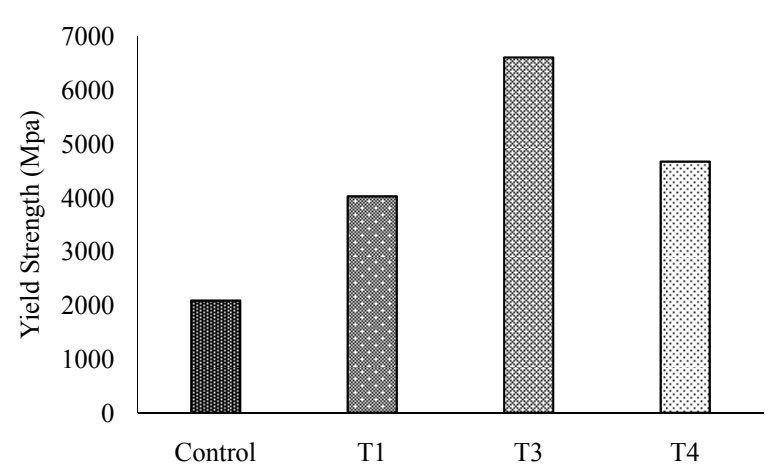

Figure 7: Effect of biofield treatment on yield strength of stainless steel.

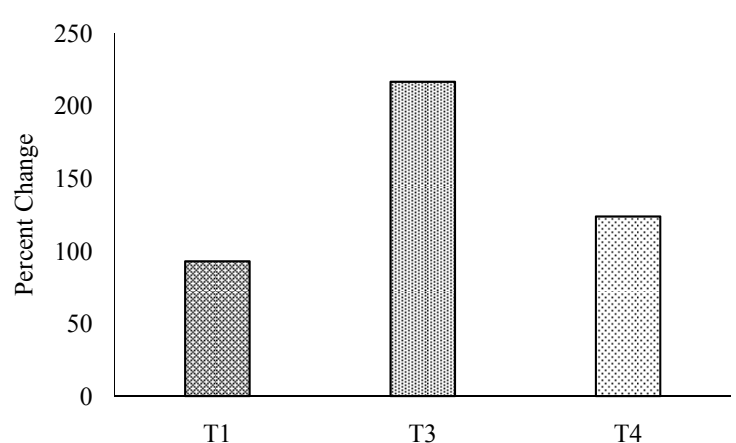

Figure 8: Effect of biofield treatment on percent change in yield strength of stainless steel as compared to control.

the crystallite boundaries. Thus, higher crystallite boundaries in treated SS powder hindered the dislocation movement gliding along the slip planes and thereby increased yield strength [4]. Thus, it is postulated that biofield treated SS powder could be more useful in automobile parts and nuclear reactor applications.

\section{FT-IR spectroscopy}

FT-IR spectrum of control and treated SS powder are shown in Figure 9. The absorption peaks observed at wavenumber 3786 and 1606 $\mathrm{cm}^{-1}$ (control) and 3759, 3450, and $1542 \mathrm{~cm}^{-1}$ (treated) were assigned to bonding vibration of water molecules due to moisture absorption by sample. Another peak observed at wavenumber $506 \mathrm{~cm}^{-1}$ in control and treated SS sample were due to $\mathrm{Cr}-\mathrm{O}$ bond vibrations [32]. Peak found at wavenumber $1107 \mathrm{~cm}^{-1}$ (control) attributed to $\mathrm{Fe}-\mathrm{O}-\mathrm{H}$ bond vibrations, was completely diminished in treated SS. It may be due to alteration in F-O-H bond at atomic level through biofield treatment [32]. Thus, it is hypothesized that biofield treatment may be acting at atomic level to cause these alteration.

\section{Conclusion}

In summary, the biofield treatment has significantly reduced the particle size and crystallite size in SS powder. Average particle size was reduced upto $12.93 \%$ in treated SS powder as compared to control. In addition, the reduction in crystallite size upto $70 \%$ after biofield treatment led to increase in yield strength by $216.57 \%$ as compared to control (Hall-Petch effect). This could be due to increase in crystallite boundaries after biofield treatment, which hindered the dislocation
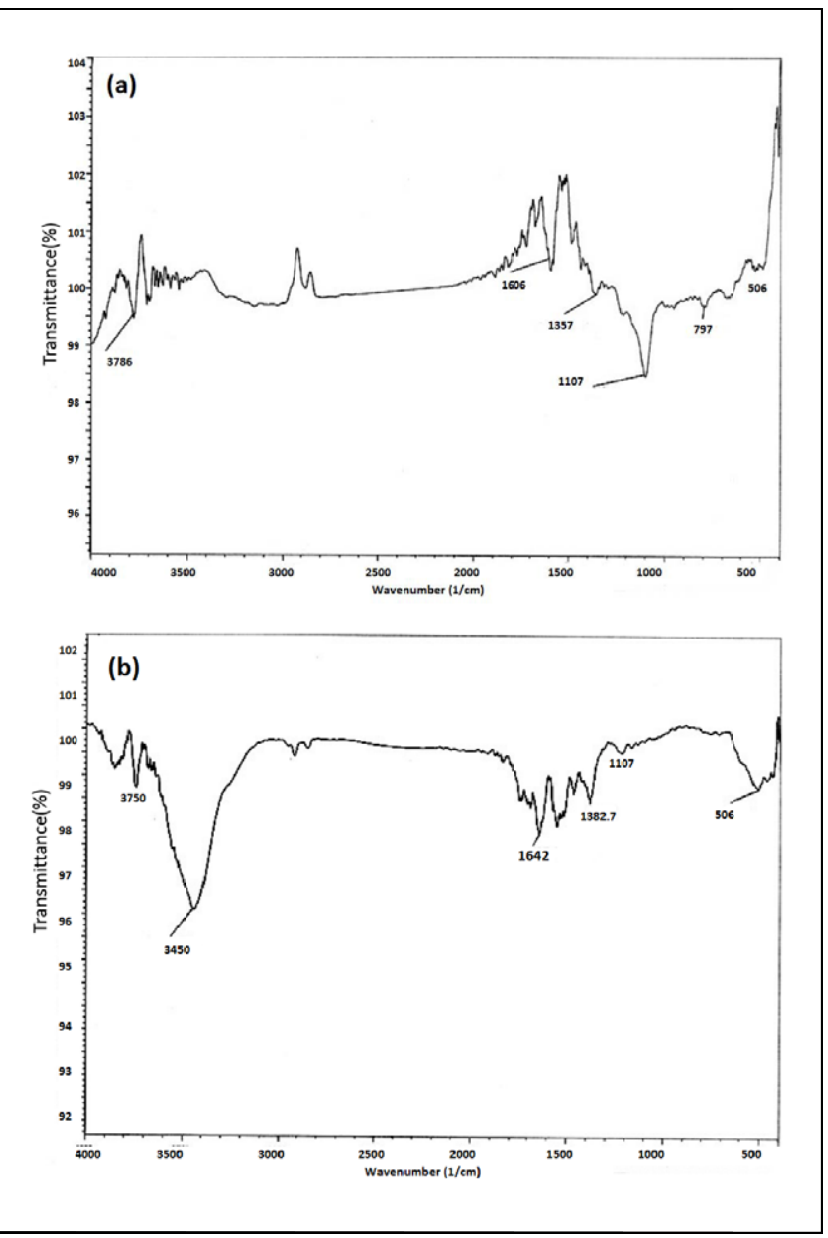

Figure 9: FT-IR spectrum of stainless steel powder (a) control and (b) treated (T1).

movement and thereby increased yield strength. FT-IR spectra showed peak at wavenumber $1107 \mathrm{~cm}^{-1}$ in control, which assigned to $\mathrm{Fe}-\mathrm{O}-\mathrm{H}$ was significantly reduced in treated SS. It might be due to alteration of bond properties in treated SS after biofield treatment. Based on these promising results, it is expected that biofield treatment could be applied to improve the mechanical properties of SS powder for nuclear reactor, appliances, and automobile.

\section{Acknowledgement}

Authors gratefully acknowledged to Dr. Cheng Dong of NLSC, Institute of Physics, and Chinese academy of Sciences for providing the facilities to use PowderX software for analyzing XRD data.

\section{References}

1. Silva G, Baldissera MR, Triches EDS, Cardoso KR (2013) Preparation and characterization of stainless steel 316L/HA biocomposite. Mater Res 16: 304-309.

2. Desu RK, Krishnamurthy HN, Balu A, Gupta AK, Singh SK (2015) Mechanical properties of austenitic stainless steel $304 \mathrm{~L}$ and $316 \mathrm{~L}$ at elevated temperatures. J Mater Res Technol (In press).

3. Meyers MA, Mishra A, Benson DJ (2006) Mechanical properties of nano crystalline materials. Prog Mater Sci 51: 427-556.

4. Callister WD (2008) Fundamentals of materials science and engineering: An integrated approach. (3rdedn), John Wiley and Sons.

5. Tanwar AK (2015) Effect of various heat treatment processes on mechanical 
Citation: Trivedi MK, Nayak G, Patil S, Tallapragada RM, Latiyal O, et al. (2015) The Potential Impact of Biofield Treatment on Physical, Structural and Mechanical Properties of Stainless Steel Powder. J Appl Mech Eng 4: 173. doi:10.4172/2168-9873.1000173

properties of mild steel and stainless steel. AIJRSTEM 57-61.

6. Tukur SA, Dambatta MS, Ahmed A, Muaz NM (2014) Effect of Heat treatment temperature on mechanical properties of the AISI 304 stainless steel. Intl J Innov Res Sci, Eng Technol 3: 9516-9520.

7. Jithin M, Hameed AA, Jose B, Jacob A (2015) Influence of heat treatment on duplex stainless steel to study the material properties. Intl J Sci Technol Res 4: 291-293.

8. Nakashima $H$ (2008) Trends in materials and heat treatments for rolling bearings. Technical Review- 76. NTN corporation Japan.

9. Del Giudice E, Doglia S, Milani M (1989) Magnetic flux quantization and josephson behavior in living systems. Phys Scrip 40: 786-791.

10. Nobili R (1985) Schrodinger wave holography in brain cortex. Phys Rev A 32: 3618-3626.

11. Popp FA (1989) Electromagnetic Bio-Information. Munchen, Baltimore: Urban \& Schwarzenberg.

12. Smith CW (1998) Is a living system a macroscopic quantum system?. Frontier Perspect 7: 9-15

13. Bohm DA (1952) Suggested interpretation of quantum theory. Phys Rev 85: 166-178.

14. Feynman RP (1949) Space-time approaches to quantum electrodynamics. Phys Rev 76: 769-782.

15. Trivedi MK, Tallapragada RM (2008) A transcendental to changing metal powder characteristics. Met Powder Rep 63: 22-28, 31.

16. Trivedi MK, Tallapragada RM (2009) Effect of super consciousness external energy on atomic, crystalline and powder characteristics of carbon allotrope powders. Mater Res Innov 13: 473-480.

17. Dhabade VV, Tallapragada RM, Trivedi MK (2009) Effect of external energy on atomic, crystalline and powder characteristics of antimony and bismuth powders. Bull Mater Sci 32: 471-479.

18. Trivedi MK, Patil S, Tallapragada RM (2012) Thought intervention through bio field changing metal powder characteristics experiments on powder characteristics at a PM plant. Proceeding of the $2^{\text {nd }}$ International conference on future control and automation 173: 247-252.

19. Trivedi MK, Patil S, Tallapragada RM (2013) Effect of biofield treatment on the physical and thermal characteristics of silicon, tin and lead powders. J Material Sci Eng 2: 125.
20. Trivedi MK, Patil S, Tallapragada RM (2013) Effect of biofield treatment on the physical and thermal characteristics of vanadium pentoxide powder. J Material Sci Eng S11: 001.

21. Trivedi MK, Patil S, Tallapragada RM (2014) Atomic, crystalline and powder characteristics of treated zirconia and silica powders. J Material Sci Eng 3: 144.

22. Trivedi MK, Patil S, Tallapragada RM (2015) Effect of biofield treatment on the physical and thermal characteristics of aluminium powders. Ind Eng Manage 4: 151.

23. Trivedi MK, Patil S, Bhardwaj $Y$ (2008) Impact of an external energy on Staphylococcus epidermis [ATCC -13518] in relation to antibiotic susceptibility and biochemical reactions - An experimental study. J Accord Integr Med 4: 230-235.

24. Trivedi MK, Patil S (2008) Impact of an external energy on Yersinia enterocolitica [ATCC -23715$]$ in relation to antibiotic susceptibility and biochemical reactions: An experimental study. Internet J Alternat Med 6.

25. Trivedi MK, Patil S, Bhardwaj $Y$ (2009) Impact of an external energy on Enterococcus faecalis [ATCC - 51299] in relation to antibiotic susceptibility and biochemical reactions - An experimental study. J Accord Integr Med 5: 119-130.

26. Patil S, Nayak GB, Barve SS, Tembe RP, Khan RR (2012) Impact of biofield treatment on growth and anatomical characteristics of Pogostemon cablin (Benth.). Biotechnology 11: 154-162.

27. Altekar N, Nayak G (2015) Effect of biofield treatment on plant growth and adaptation. J Environ Health Sci 1: 1-9.

28. Shinde V, Sances F, Patil S, Spence A (2012) Impact of biofield treatment on growth and yield of lettuce and tomato. Aust J Basic Appl Sci 6: 100-105.

29. Lenssen AW (2013) Biofield and fungicide seed treatment influences on soybean productivity, seed quality and weed community. Agricultural Journal 8: 138-143.

30. Sances F, Flora E, Patil S, Spence A, Shinde V (2013) Impact of biofield treatment on ginseng and organic blueberry yield. Agrivita J Agric Sci 35.

31. Singh KK, Sangal S, Murty GS (2002) Hall-Petch behaviour of 316L austenitic stainless steel at room temperature. Mater Sci Technol 18: 165-172.

32. Junqueira RMR, Loureiro CRDO, Andrade MS, Buono VTL (2008) Characterization of interference thin films grown on stainless steel surface by alternate pulse current in a sulphochromic solution. Mat Res 114: 421-426. 